\title{
Interference Periods of Weeds Infesting Maize Crop
}

\author{
Leandro Galon ${ }^{1}$, Maico André Michelon Bagnara ${ }^{1}$, Ricardo Luis Gabiatti ${ }^{1}$, Francisco Wilson Reichert Júnior ${ }^{2}$, \\ Felipe José Menin Basso ${ }^{1}$, Felipe Nonemacher ${ }^{1}$, Luciane Renata Agazzi ${ }^{3}$, \\ Lauri Lourenço Radunz ${ }^{4} \&$ César Tiago Forte ${ }^{5}$ \\ ${ }^{1}$ Dpartmet of Agronomy, Federal University of Fronteira Sul, Erechim, Brazil \\ ${ }^{2}$ Department of Genetic Resources, Federal University of Santa Catarina, Florianópolis, Brazil \\ ${ }^{3}$ Department of Agronomy, Federal University of Viçosa, Viçosa, Brazil \\ ${ }^{4}$ Department of Agronomy, Federal University of Rio Grande do Sul, Porto Alegre, Brazil \\ ${ }^{5}$ Department of Agronomy, Federal University of Santa Maria, Santa Maria, Brazil \\ Correspondence: César Tiago Forte, Department of Agronomy, Federal University of Santa Maria, Santa Maria, \\ Brazil. Tel: 55-54-9-9688-9706. E-mail: cesartiagoforte@hotmail.com
}

$\begin{array}{lcc}\text { Received: June 10, } 2018 & \text { Accepted: July 16, } 2018 & \text { Online Published: September 15, } 2018 \\ \text { doi:10.5539/jas.v10n10p197 } & \text { URL: https://doi.org/10.5539/jas.v10n10p197 }\end{array}$

\begin{abstract}
When competing with crops, weeds interfere with their growth and consequently reduce grain yield. The purpose of this research was to determine the periods of interference; PIP (pre-interference period), TPWC (total period of weed control), and CPWC (critical period of weed control) of the weeds Alexandergrass (Urochloa plantaginea) and southern crabgrass (Digitaria ciliares) in maize. The experiment was conducted in a randomized complete block design with four replications, in a no-tillage system. The treatments consisted in maintaining maize in the presence and absence of Alexandergrass and southern crabgrass for increasing periods of $0,7,14,21,28,35$ and 42 days after emergence (DAE). Southern crabgrass and Alexandergrass weeds originated from the soil seed bank with an average density of 215 and 87 plants $\mathrm{m}^{-2}$, respectively. At the end of each period, PIP or TPWC, the weed and crop dry biomass was determined. At 42 DAE, the height and stem diameter of maize plants were evaluated. At harvest 10 maize plants per experimental unit were evaluated for length of ears, number of rows per ear, and number of grains per row. Yield was measured by taking three central rows from each experimental unit. The results indicate that the PIP was 17 DAE, the TPWC was 32 DAE, and the CPWC was 17 to $32 \mathrm{DAE}$.
\end{abstract}

Keywords: Digitaria ciliares, Urochloa plantaginea, Zea mays

\section{Introduction}

Maize (Zea mays L.) is one of the most important crops in the world, used for both human and animal consumption or even for energy production. In Brazil, maize is one of the most economically and socially important crops, with an estimate of 4.97 million hectares in production, yielding $5.05 \mathrm{t} \mathrm{ha}^{-1}$, and producing 92.34 million tons in the $2017 / 18$ crop year (CONAB, 2017).

However, maize productivity is lower than that obtained in areas that adopt high technological levels or experimental areas, because it is affected by several factors. Weed competition is the primary factor limiting maize's full productive potential, therefore, there is an increase interest in weeds negative impacts on production (Luke \& Thieret, 1997; Safdar et al., 2015).

It is estimated that yield losses in maize as a function of competition with weeds are in the order of $13 \%$ (Carvalho et al., 2007). In many situations, where no control measures are adopted, this reduction can reach $85 \%$ (Carvalho et al., 2007) or more than 90\% (Merotto Jr. et al., 1997; Galon et al., 2008).

Among the weeds that cause interference in crops of agricultural interest in Brazil, Alexandergrass (Urochloa plantaginea) and southern crabgrass (Digitaria ciliaris) stand out due to their high competitive ability (Fleck et al., 2002; Agostinetto et al., 2013). Weeds damage the development of agricultural crops as they compete for environmental resources such as water, light, space and nutrients. Alexandergrass is considered a detrimental companion plant of maize and, when living with the crop, reduces the availability of the resources, as reported by Galon et al. (2008). Also, the southern crabgrass when competing with rice and soybean negatively affected 
the productivity of these crops (Agostinetto et al., 2013). As a result, it is mandatory to manage Alexandergrass and southern crabgrass when they infest these crops, especially maize, as they belong to the same botanical family (Poaceae) and will therefore compete for similar environmental resources.

Weeds have the greatest negative impact, around 37\%, compared to insects $(18 \%)$, fungi and bacteria (16\%) and viruses $(2 \%)$ (Oerke, 2006). The magnitude of the loss is related to the composition of the weed flora, weed emergence timing in relationship to the crop, weed density, intensity and crop development stage in relation to the period of competition (Singh et al., 2016). The competition with maize in the stage of 5 fully expanded leaves has the most negative interference to the crop, since it is in this phase that the components related to grain yield are established (Duarte et al., 2002).

Knowing the appropriate period for weed management helps in decision for the application any control measure. The critical period of competition is defined as the shortest possible period in the life cycle of a crop in which weed control has the highest economic return (Nazir, 1994; Safdar et al., 2016). The period of cohabitation of the weed crop can be divided into: a) pre-interference period (PIP), period from the sowing, the crop can live with the weeds without reducing the productivity; b) total period of weed control (TPWC), that from the emergence of the crop, in which weeds must be controlled so that the crop exerts its maximum productive potential; c) critical period of weed control (CPWC), corresponds to the difference between the PIP and the TPWC, when the crop should be effectively weed-free. The knowledge of these periods helps to carry out the necessary managements for the control of weeds in maize (Pitelli \& Durigan, 1984; Galon et al., 2008).

In maize, there is a significant reduction in grain yield when the crop competes with weeds for increasing periods of time. In addition, weed infestation in maize for the period of 2 to 6 weeks, depending on the development stage of the crop, may lead to a high yield reduction (Hall et al., 1992; Safdar et al., 2016), since is in the initial development stages that the yield components are stablished. However, the critical period for control varies from 11 to 56 days after emergence (DAE) of the culture. This variation occurs due to several factors, such as the species and population of weeds present in the area, maize cultivar, fertility and soil moisture, as well as the sowing season (Severino et al., 2005; Duarte et al., 2007; Galon et al., 2008).

The objective of this research was to determine the interference periods; PIP (pre-interference period), TPWC (total period of weed control), and CPWC (critical period of weed control), of Alexandergrass (Urochloa plantaginea) and southern crabgrass (Digitaria ciliaris) weeds.

\section{Method}

\subsection{Field Descriptions and Experimental Design}

The experiment was conducted in the experimental area of the Federal University of Fronteira Sul, Câmpus Erechim. The soil of the site is classified as Red Latosol (Embrapa, 2013), sowing was by no-till in the straw. Correction of soil fertility was carried out according to soil chemical analysis and followed the fertilization recommendations for maize.

The experimental was a randomized complete block design with four replications. The research plots measured $15 \mathrm{~m}^{2}(3 \mathrm{~m} \times 5 \mathrm{~m})$ with a working area of the plot of $8 \mathrm{~m}^{2}(2.0 \mathrm{~m} \times 4 \mathrm{~m})$. On Nov. 20, 2015, a Velox hybrid maize with hyperprecose cycle (125 days) was seeded in 0.5 row spacings at an average density of 3.0 plants per meter with a final population of approximately 60,000 plants ha ${ }^{-1}$. Fertilizer, $327 \mathrm{~kg} \mathrm{ha}^{-1}$ (05-30-15 N-P-K), while nitrogen $\left(90 \mathrm{~kg} \mathrm{ha}^{-1}\right)$ was applied at two plant growth stages, V5 and V8, for each.

A weed population survey of the experimental area determined that there was an average population of 215 and $87 \mathrm{~m}^{-2}$ plants of Urochloa plantaginea (Alexandergrass) and Digitaria ciliaris (Southern crabgrass), respectively. All of weed species in the experimental area were eliminated manually.

The treatments were separated into two interference models. In the first model (cohabitation) maize was grown with Alexandergrass and southern crabgrass for increasing periods of $0,7,14,21,28,35$ and 42 days after emergence (DAE) and in the second model (control), the crop was kept weed free for 0, 7, 14, 21, 28, 35 and 42 DAE.

\subsection{Data Collection}

At the end of each period of weed cohabitation or control with maize, the weed population (Alexandergrass and southern crabgrass) and the dry mass of the species were evaluated using a square of $0.5 \mathrm{~m} \times 0.5 \mathrm{~m}$ in the center of each experimental unit. After determining the plant population, the plants were cut at the soil surface, placed in paper bags, and dried in a forced circulation oven at $60^{\circ} \mathrm{C}$ until the mass reached constant weight. 
At 42 DAE, the height and diameter of 10 randomly selected maize plants were determined. Maize plant height was measured using a with ruler graduated in millimeters from the soil surface to the last fully developed leaf. Maize stem diameters were measured using a digital caliper at $5 \mathrm{~cm}$ above the soil surface. To evaluate the grain yield components of preharvest maize, 10 plants per experimental unit were collected to determine the length of maize ears, the number of kernel rows per ear, and the number of kernels per row. To obtain productivity, the ears were collected in $4.5 \mathrm{~m}^{2}(3.0 \mathrm{~m} \times 1.5 \mathrm{~m})$ quadrants of each experimental unit. The grain moisture content was determined as described in RAS (2009). The yield was then adjusted to $13 \%$ moisture and the values extrapolated to $\mathrm{tha}^{-1}$.

\subsection{Statistical Analysis}

Data were subjected to analysis of variance by the F test. Interfering periods: PIP, TPWC and CPWC of the Alexandergrass and southern crabgrass species on maize were determined using the grain yield variable $\left(\mathrm{t} \mathrm{ha}^{-1}\right)$.

For the other variables, the Tukey test was applied to compare the effects of coexistence and control periods between weeds and the crop; and the Minimum Significant Difference (MSD) test to evaluate the differences between the control and cohabitation periods on the crop plants in each treatment (Pimentel-Gomes, 1990). All data were analyzed at 5\% probability using the Winstat (2002) computer program.

The yield data, standardized to $13 \%$ dry basis moisture and expressed as $\mathrm{t} \mathrm{ha}^{-1}$, were submitted to regression analysis by the nonlinear regression model. This model follows the following logistic equation:

$$
Y=\frac{a}{1+e^{[-(x-x o) / b]}}
$$

Where, $Y=$ grain yield, $\mathrm{x}=$ number of days after emergence of maize crop; $\mathrm{a}=$ maximum value of the curve; and $\mathrm{b}=$ slope of the curve; and $\mathrm{xo}=$ value of $\mathrm{x}$ at the midpoint of the sigmoid curve. Based on the regression equations, the periods of interference of Alexandergrass and southern crabgrass on maize were determined. Being subtracted $5 \%$ of the estimated maximum productivity in the regression equations in relation to the treatment maintained in the absence of infestation, considered as cost of adopting chemical control.

\section{Results and Discussion}

\subsection{Effect of Competition on Morphological Characteristics}

The maize plant height and stem diameter, were affected by competition with Alexandergrass and southern crabgrass weeds (Table 1). A reduction in stem diameter and maize height was observed as the maize coexisted longer with weeds, that is, from 0 to $42 \mathrm{DAE}$. For the weed control model treatments, there were no differences, except for the stem diameter at $0 \mathrm{DAE}$, which was lower than the other weed control periods. There was a small change in plant height in the cohabitation periods in relation to the control period. These results are consistent with Galon et al. (2008) who observed a cessation in maizedevelopment due to periods of interference with Alexandergrass. It should be noted that stem diameter and plant height were greater shortly after crop emergence, that is, in the initial periods of cohabitation with weeds. This is due to the competition between crop and weeds, mainly for light. Light competition may cause plants to invest more in stem development rather than other parts of the plant, to achieve higher stature as a strategy to increase light uptake (Page et al., 2010). The light resource is one of the main limiters of the initial growth of the plant community and may directly reflect the productive potential of the crop (Page et al., 2010).

In general, no difference was found between the coexistence and control periods, only differentiation occurred at 0 and 21 DAE for stem diameter. This fact can be explained by the growth and development of weeds, especially those that emerged at the beginning of the cycle, suppressing the development of the following ones and reducing the intensity of competition on the crop (Radosevich et al., 1997; Galon et al., 2008). 
Table 1. Velox hybrid maize stem diameter and plant height at 42 days after emergence (DAE) as a function of cohabitation and weed control periods with southern crabgrass (Digitaria ciliaris) and Alexandergrass (Urochloa plantaginea) weeds. UFFS, Campus Erechim/RS

\begin{tabular}{|c|c|c|c|c|}
\hline \multirow{2}{*}{ Period in $\mathbf{D A E}^{1}$} & \multicolumn{2}{|c|}{ Stem diameter $(\mathrm{cm})$} & \multicolumn{2}{|c|}{ Plant height (m) } \\
\hline & Cohabitation $^{2}$ & Control $^{2}$ & Cohabitation & Control \\
\hline 0 & $3.20 \mathrm{a}^{*}$ & $1.94 b^{*}$ & $2.16 \mathrm{a}$ & $2.07^{\mathrm{ns}}$ \\
\hline 7 & $2.89 \mathrm{~b}$ & $2.55 \mathrm{a}$ & $2.17 \mathrm{a}$ & 2.16 \\
\hline 14 & $3.00 \mathrm{ab}$ & $2.78 \mathrm{a}$ & $2.09 \mathrm{ab}$ & 2.12 \\
\hline 21 & $2.80 \mathrm{~b}^{*}$ & $2.51 \mathrm{a}^{*}$ & $2.11 \mathrm{ab}$ & 2.15 \\
\hline 28 & $2.39 \mathrm{c}$ & $2.69 \mathrm{a}$ & $2.01 \mathrm{~b}$ & 2.09 \\
\hline 35 & $2.16 \mathrm{~cd}$ & $2.43 \mathrm{ab}$ & $2.07 \mathrm{ab}$ & 2.01 \\
\hline 42 & $2.07 \mathrm{~d}$ & $2.52 \mathrm{a}$ & $2.04 \mathrm{ab}$ & 2.08 \\
\hline General Average & 2.64 & 2.49 & 2.09 & 2.10 \\
\hline CV(\%) & 4.08 & 9.17 & 2.99 & 5.43 \\
\hline
\end{tabular}

Note. ${ }^{1}$ DAE: days after emergence of maize. ${ }^{2}$ Averages followed by the same letter in the column do not differ by Tukey test $(\mathrm{p} \leq 0.5) .{ }^{*}$ significant by the "t" test $(\mathrm{p} \leq 0.05)$.

Maize stem diameter was reduced by $35.4 \%$ at 42 DAE in relation to the control period (0 DAE). These reductions in stem diameter and maize plant height occured when a plant reallocates energy for growth in the early stages to compete with the weed in the search for light. This behavior occurs in situations of high plant populations, both weed and crop. Similar results were also reported by Dourado Neto et al. (2003) when studying the effect of plant population and spacing on maize yield. In high populations, plants respond with a more rapid initial growth to overcome the competition for light, sacrificing the development of stem diameter and other variables, and may even negatively affect grain yield (Brachtvogel et al., 2012).

\subsection{Effects of Competition on Maize Grain Yield Components}

The results show that the length of ears and the number of grains per row were not significantly different for the cohabitation and control periods in all evaluated periods, from 0 to 42 DAE (Table 2). To evaluate the length of maize ears as a function of the coexistence with B. plantaginea, Galon et al. (2008) concluded that the length of the ears was affected by weed interference.

Table 2. Ear length and number of kernels per row of the Velox maize hybrid according to the periods of cohabitation and control of southern crabgrass (Digitaria ciliaris) and Alexandergrass (Urochloa plantaginea) weeds. UFFS, Campus Erechim/RS

\begin{tabular}{|c|c|c|c|c|}
\hline \multirow{2}{*}{ Period in DAE ${ }^{1}$} & \multicolumn{2}{|c|}{ Ear lenght (cm) } & \multicolumn{2}{|c|}{ Kernels per row } \\
\hline & Cohabitation $^{2}$ & Control $^{2}$ & Cohabitation $^{2}$ & Control $^{2}$ \\
\hline 0 & $16.42^{\mathrm{ns}}$ & $15.22^{*}$ & $31.66^{\mathrm{ns}}$ & 29.37 \\
\hline 7 & 16.64 & 15.86 & 32.54 & 31.75 \\
\hline 14 & 16.26 & 16.19 & 31.79 & 33.41 \\
\hline 21 & 16.40 & 16.40 & 33.04 & $31.58 *$ \\
\hline 28 & 16.34 & 16.33 & 30.79 & 32.96 \\
\hline 35 & 16.27 & 15.83 & 33.87 & 30.58 \\
\hline 42 & 15.65 & 16.65 & 30.75 & 32.00 \\
\hline General average & 16.28 & 16.07 & 32.06 & 31.66 \\
\hline CV $(\%)$ & 4.10 & 4.16 & 7.92 & 6.92 \\
\hline
\end{tabular}

Note. ${ }^{1}$ DAE: days after emergence of maize. ${ }^{n s}$ not significant. ${ }^{*}$ significant by the "t" test $(\mathrm{p} \leq 0.05)$.

It was observed, when comparing the coexistence and the control, that was a statistical difference between both for the ear length at $0 \mathrm{DAE}$ and at $21 \mathrm{DAE}$ for the number of kernels per ear. Similar behavior was observed by Spader and Vidal (2000), observing that the competition between crop and weeds decreased ear length and number of kernels, mainly in the early crop development, where they compete more intensively for the environment al resources. 
The number of kernel rows per ear did not result in significant differences when the maize coexisted with weeds (Table 3). For the same variable when evaluating the control, it was observed that only weeding at 35 DAE showed differentiation in relation to 7,14 and $21 \mathrm{DAE}$ and was statistically equal to 0,28 and $42 \mathrm{DAE}$. When comparing the periods between them, it was verified that there were differences in the $28 \mathrm{DAE}$, for example, the number of kernel rows per ear was greater in the control in relation to the coexistence. Zagonel et al. (2000) found similar behavior when observing a reduction in the number of kernel rows per ear of maize in competition with weeds.

The results show a negative effect on maize dry mass during growing periods with Alexandergrass and southern crabgrass, that is, from 0 to $42 \mathrm{DAE}$ (Table 3). For the control period, the opposite was observed, that is, as the weed management increased, the dry mass of the crop increased. The dry mass of the maize was reduced by $39 \%$ when cohabitating with weeds up to $28 \mathrm{DAE}$, compared to the control (0 DAE), and $41.5 \%$ to $42 \mathrm{DAE}$ in the weed management periods. These results agree with those obtained by Rossi et al. (1996) when they observed a reduction of 26 and $39 \%$ in the maize biomass accumulation at 35 days after sowing, competing with different weed species.

The results obtained in this work demonstrate a reduction in the maize dry mass from 7 DAE when in the presence of the both weed species (Table 3). As previously reported, similar results were found by Rossi et al. (1996) when evaluating the accumulation of biomass in leaves and stems at 35 days after sowing.

In relation to maize grain yield components, it was possible to observe that there was negative interference when the crop was in the presence of the southern crabgrass and Alexandergrass weeds (Table 3). Kozlowski (2002), when evaluating the effect of competition on maize phenology, concluded that in respect to grain yield components, the crop should be free of competition between phenological stages $\mathrm{V} 2$ to $\mathrm{V} 7$, since at this stage the plant is differentiating all components related to grain yield.

Table 3. Number of kernel rows per ear and dry mass of the aerial part of the Velox maize hybrid as a function of the cohabitation and control periods with southern crabgrass (Digitaria ciliaris) and Alexandergrass (Urochloa plantaginea) weeds. UFFS, Campus Erechim/RS

\begin{tabular}{|c|c|c|c|c|}
\hline \multirow{2}{*}{ Period in DAE ${ }^{1}$} & \multicolumn{2}{|c|}{ Number of kernel rows per ear } & \multicolumn{2}{|c|}{ Dry mass (g) } \\
\hline & Cohabitation & Control & Cohabitation & Control \\
\hline 0 & $20.21^{\mathrm{ns}}$ & $19.48 \mathrm{ab}$ & $190.87 \mathrm{a}^{*}$ & $104.37 \mathrm{~b}^{*}$ \\
\hline 7 & 20.73 & $20.16 \mathrm{a}$ & $145.38 \mathrm{~b}^{*}$ & $126.03 \mathrm{ab}^{*}$ \\
\hline 14 & 19.83 & $20.33 \mathrm{a}$ & $177.26 \mathrm{a}^{*}$ & $128.05 \mathrm{ab}^{*}$ \\
\hline 21 & 19.75 & $20.16 \mathrm{a}$ & $145.37 \mathrm{~b}$ & $150.24 \mathrm{a}$ \\
\hline 28 & 19.00 & $19.75 \mathrm{ab}^{*}$ & $116.60 \mathrm{c}^{*}$ & $146.32 \mathrm{a}^{*}$ \\
\hline 35 & 19.33 & $18.83 \mathrm{~b}$ & $121.19 \mathrm{c}$ & $126.49 \mathrm{ab}$ \\
\hline 42 & 19.42 & $19.42 \mathrm{ab}$ & $111.79 \mathrm{c}$ & $117.50 \mathrm{ab}$ \\
\hline General average & 19.75 & 19.73 & 144.07 & 128.43 \\
\hline CV $(\%)$ & 3.92 & 2.03 & 6.51 & 11.63 \\
\hline
\end{tabular}

Note. ${ }^{1}$ DAE: days after emergence of maize. ${ }^{2}$ Averages followed by the same letter in the column do not differ by Tukey test $(\mathrm{p} \leq 0.05) .{ }^{*}$ and ${ }^{\mathrm{ns}}$ significant and non-significant, respectively by the " $\mathrm{t}$ " test $(\mathrm{p} \leq 0.05)$.

\subsection{Periods of Interference and Effect of Competition on Maize Yield}

There was an increase in the weed dry mass during the periods of coexistence between the species, as opposed to maize that presented linear reduction during the same period (Figure 1). These results corroborate those found by Maqbool et al. (2006) and Safdar et al. (2016) who observed an increase in weed biomass during periods of coexistence with maize. 


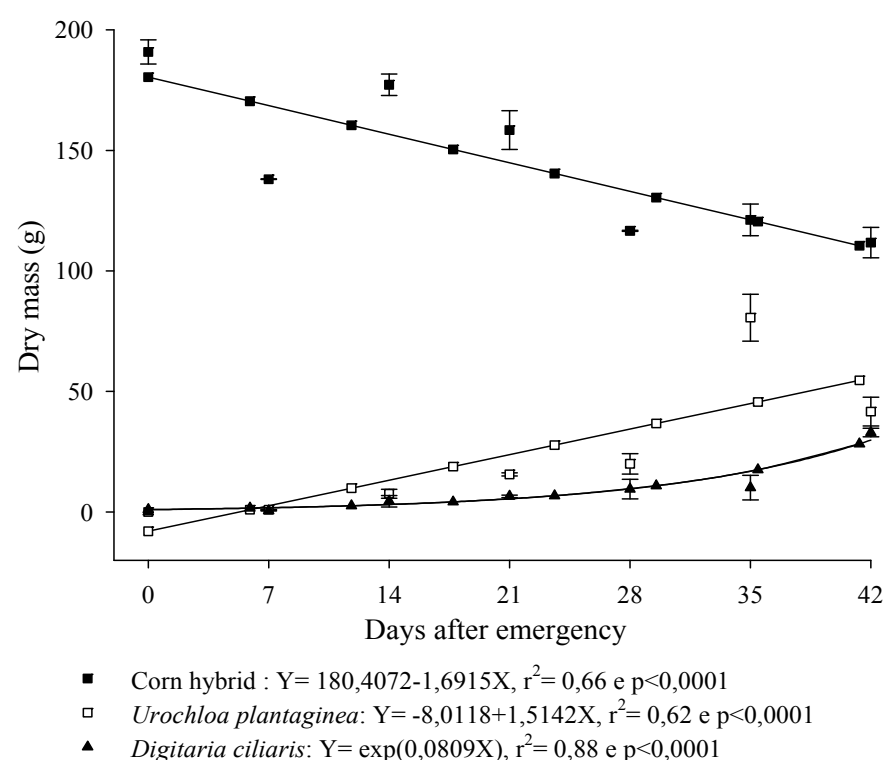

Figure 1. Dry mass (g) of the Velox maize hybrid (•), Alexandergrass-Urochloa plantaginea ( $\square$ ) and Southern crabgrass-Digitaria ciliaris ( $\mathbf{\Delta})$ accumulated during the periods of cohabitation of the crop with weeds. UFFS, Campus Erechim/RS

For the control periods (Figure 2), there was an opposite effect compared to the coexistence treatments in respect to the weeds that were controlled during the initial infestation stages of the maize, allowing the crop to develop a greater dry mass, without as much interference and losses caused by the interference of the southern crabgrass and Alexandergrass weeds.

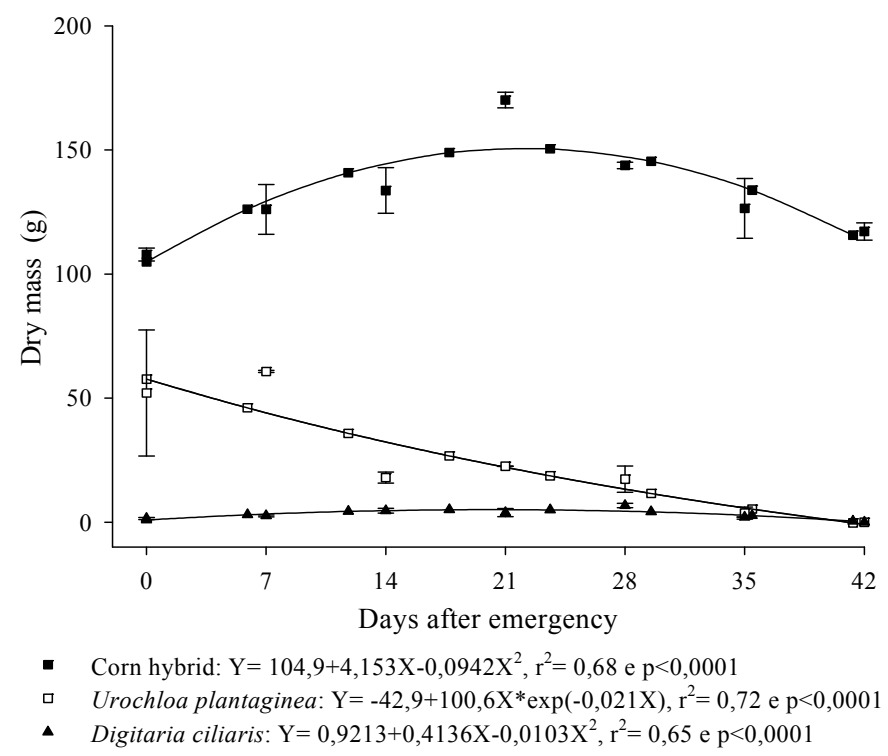

Figure 2. Dry mass (g) of the Velox maize hybrid (•), Alexandergrass-Urochloa plantaginea ( $\square$ ) and southern crabgrass-Digitaria ciliaris (A) accumulated during crop control periods with weeds. UFFS, Campus Erechim/RS

Figure 3 shows the maize productivity curves in coexistence or when the control of the Alexandergrass and the southern crabgrass was carried out. The weeds began to affect maize yield from 17 DAE, denoting the need to control the Alexandergrass and/or the southern crabgrass weeds, establishing a total period of weed control (TPWC) 32 DAE. 
The period between 17 and 32 DAE was characterized by the critical period for weed control (CPWC), which during this time it is recommended that the crop remains free from weed competition (Figure 3). The period in which weeds can coexist with the crop with no major damage to productivity (PIP) was established as the time prior to $17 \mathrm{DAE}$, after which weed control should be performed.

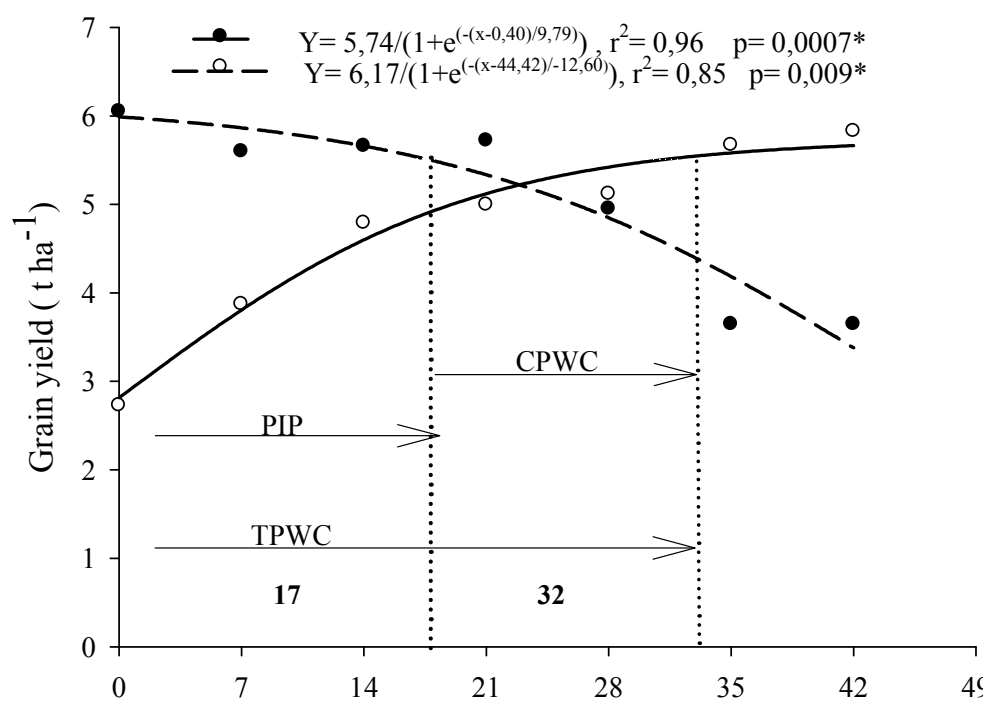

Figure 3. Grain yield of the Velox maize hybrid $\left(\mathrm{t} \mathrm{ha}^{-1}\right)$, depending on the periods of coexistence $(\bullet)$ and control (०) of southern crabgrass (Digitaria ciliaris) and Alexandergrass (Urochloa plantaginea). PIP: pre-interference period; TPWC: total period for weed control and CPWC: critical period for weed control. * Significant at $\mathrm{p} \leq$ 0.05. UFFS, Campus Erechim/RS

The results were consistent with those reported by Galon et al. (2008), Tursun et al. (2016) and Safdar et al., (2016), who found CPWC between 11 and 27 DAE, 17 and 30 DAE, and 22 and 35 DAE, respectively. These values vary do to the year of cultivation, weed community, edaphoclimatic characteristics, cultivars, management system, among other influences (Karam et al., 2010). These values are based on an average loss of productivity of 5 to $10 \%$, which is considered the control cost for the management of weeds (Pitelli \& Durigan, 1984).

The results obtained in this study show that yield losses reach around 53\% when weeds competed with the crop during the entire cycle, corroborating the results by Tursun et al. (2016), in which they observed that the increase of period of weed interference in three types of maize resulted in a significant reduction in productivity in a two-year study, with losses varying from 51 to $72 \%$ in maize for grain, 50 to $79 \%$ in popcorn, and 47 to $54 \%$ in sweet corn. Therefore, weed control becomes essential to avoid maize yield losses, as observed in other studies (Kozlowski, 2002; Galon et al., 2008; Vivek et al., 2008; Safdar et al., 2016; Tursun et al., 2016).

According to the results obtained and using observations by Pitelli and Durigan (1984), it was concluded that the total period for weed control (TPWC) was $32 \mathrm{DAE}$ and the duration of the pre-interference period (PIP) was 17 DAE. Thus, it is evident in this study that the control of the plants southern crabgrass and Alexandergrass must be initiated in the period of 17 to $32 \mathrm{DAE}$, during the period considered as critical for weed control (CPWC), allowing the crop to express total productive potential, according to local soil and climatic conditions.

The definition of CPWC in maize and other crops is an extremely important tool for the adoption of integrated weed management to avoid losses and unnecessary use of herbicides. However, the precise determination of this period is complex, because factors such as sowing time and crop plant population; nitrogen application rates and timing, species and weed populations present; and soil and climatic characteristics can vastly influence the results, causing differences in different locations and years.

\section{Conclusions}

According to the results obtained, the total period for weed control (TPWC) was 32 DAE and the duration period before interference (PIP) of 17 DAE. Thus, it is evident in this study that the control of southern crabgrass and Alexandergrass must be initiated in the period of 17 to $32 \mathrm{DAE}$, during the period considered as critical for weed 
control (CPWC), allowing the crop to fully express its productive potential, according to local soil and climatic conditions. Determining the CPWC in maize and other crops is an extremely important tool for the adoption of integrated weed management in order to avoid yield reductions and unnecessary use of herbicides.

\section{References}

Agostinetto, D., Fontana, L. C., Vargas, L., Markus, C., \& Oliveira, E. de. (2013). Habilidade competitiva relativa de milhã em convivência com arroz irrigado e soja. Pesquisa Agropecuária Brasileira, 48, 1315-1322. https://doi.org/10.1590/S0100-204X2013001000002

Agostinetto, D., Moraes, P. V. D., Oliveira, C., Markus, C., \& Galon, L. (2012). Potencial alelopático de extratos aquosos de culturas de cobertura de solo sobre a germinação e desenvolvimento inicial de Digitaria spp. Revista Cientifica Rural, 14, 111-129.

Cataneo, A. C., Déstro, G. F. G., Ferreira, L. C., Chamma, K. L., \& Sousa, D. C. F. (2003). Atividade de glutationa s-transferase na degradação do herbicida glyphosate em plantas de milho (Zea mays). Planta Daninha, 21, 307-312. https://doi.org/10.1590/S0100-83582003000200017

Coelho, M., Bianco, S., \& Carvalho, L. B. (2009). Interferência de plantas daninhas na cultura da cenoura (Daucus carota). Planta Daninha, 27, 913-920. https://doi.org/10.1590/S0100-83582009000500004

CONAB (Companhia Nacional de Abastecimento). (2017). Série Histórica de: Área, produtividade e produção. Milho, Brasil. Retrieved from http://www.conab.gov.br

Costa, N. V., Cardoso, L. A., Rodrigues, A. C. P., \& Martins, D. (2008). Períodos de interferência de uma comunidade de plantas daninhas na cultura da batata. Planta Daninha, 26, 83-91. https://doi.org/10.1590/ S0100-83582008000100009

Culpepper, A. S., \& York, A. C. (2000). Weed management in ultra narrow row cotton (Gossypium hirsutum). Weed Technology, 14, 19-29. https://doi.org/10.1614/0890-037X(2000)014[0019:WMIUNR]2.0.CO;2

Duarte, N. F., Silva, J. B., \& Souza, I. F. (2002). Competição de plantas daninhas com a cultura do milho no município de Ijaci, MG. Ciência e Agrotecnologia, 26, 983-992.

EMBRAPA (Empresa Brasileira de Pesquisa Agropecuária). (2013). Sistema brasileiro de classificação de solos (p. 353). Brasília, DF: Embrapa Solos.

Fleck, N. G., Rizzardi, M. A., \& Agostinetto, D. (2002). Nível de dano econômico como critério para tomada de decisão no controle de guanxuma em soja. Planta Daninha, 20, 421-429. https://doi.org/10.1590/S0100835 82002000300013

Fleck, N. G., Rizzardi, M. A., Vidal, R. A., Merotto Jr., A., Agostinetto, D., \& Balbinot Jr., A. A. (2002). Período crítico para controle de Brachiaria plantaginea em função de épocas de semeadura da soja após dessecação da cobertura vegetal. Planta Daninha, 20, 53-62. https://doi.org/10.1590/S0100-83582002000100008

Galon, L., Pinto, J. J. O., Rocha, A. A., Concenço, G., Silva, A. F., Aspiazú, I., ... Pinho, C. F. (2008). Período de interferência de Brachiaria plantaginea na cultura do milho na região sul do Rio Grande do Sul. Planta Daninha, 26, 779-778. https://doi.org/10.1590/S0100-83582008000400009

Harrison, H. F., \& Jackson, D. M. (2011). Response of two sweet potato cultivars to weed interference. Crop Protection, 30, 1291-1296. https://doi.org/10.1016/j.cropro.2011.05.002

Karkanis, A., Bilalis, D., Efthimiadou, A., \& Katsenios, N. (2012). The critical period for weed competition in parsley (Petroselinum crispum (Mill.) Nyman ex AW Hill) in Mediterranean areas. Crop Protection, 42, 268-272. https://doi.org/10.1016/j.cropro.2012.07.003

Kozlowski, L. A. (2002). Período crítico de interferência das plantas daninhas na cultura do milho baseado na fenologia da cultura. Planta Daninha, 20, 365-372. https://doi.org/10.1590/S0100-83582002000300006

Kuva, M. A., Gravena, R., Pitelli, R. A., Christoffoleti, P. J., \& Alves, P. L. C. A. (2003). Períodos de interferência das plantas daninhas na cultura da cana-de-açúcar: III-capim-braquiária (Brachiaria decumbens) e capim-colonião (Panicum maximum). Planta Daninha, 21, 37-44. https://doi.org/10.1590/ S0100-83582003000100005

Merotto Jr., A., Pitelli, R. A., Vidal, R. A., Schumm, K. C., \& Fleck, N. G. (2000). Redução da interferência de Brachiaria plantaginea (Link) Hitch. em milho através de capinas e aplicação de herbicidas em diferentes épocas. Planta Daninha, 18(3), 471-477. 
Merotto Jr., A., Vidal, R. A., Fleck, N. G., \& Almeida, M. L. (2002). Interferência das plantas daninhas sobre o desenvolvimento inicial de plantas de soja e arroz através da qualidade da luz. Planta Daninha, 20, 9-16. https://doi.org/10.1590/S0100-83582002000100002

Meschede, D. K., Oliveira Jr., R. S., Constantin, J., \& Scapim, C. A. (2002). Período crítico de interferência de Euphorbia heterophylla na cultura da soja sob baixa densidade de semeadura. Planta Daninha, 20, 381-387. https://doi.org/10.1590/S0100-83582002000300008

Oerke, E. C. (2006). Crop losses to pests. Journal of Agricultural Science, 144, 31-43. https://doi.org/10.1017/ S0021859605005708

Page, E. R., Tollenaar, M., Lee, E. A., Lukens, L., \& Swanton, C. J. (2010). Shade avoidance: An integral component of crop-weed competition. Weed Research, 50, 281-288. https://doi.org/10.1111/j.1365-3180. 2010.00781.x

Pimentel-Gomes, F. (1990). Curso de Estatística Experimental. São Paulo, SP: Nobel.

Rossi, I. H., Osunas, J. A., Alves, P. L. C. A., \& Bezutte, A. J. (1996). Interferência das plantas daninhas sobre algumas características agronômicas e produtividade de sete cultivares de milho. Planta Daninha, 14, 134-148. https://doi.org/10.1590/S0100-83581996000200007

Safdar, M. E., Tanveer, A., Khaliq, A., \& Maqbool, R. (2016). Critical competition period of parthenium weed (Parthenium hysterophorus L.) in maize. Crop Protection, 80, 101-107. https://doi.org/10.1016/ j.cropro.2015.11.002

Salgado, T. P., Alves, P. L. C. A., Mattos, E. D., Martins, J. F., \& Hernandez, D. D. (2002). Períodos de interferência das plantas daninhas na cultura do algodoeiro (Gossypium hirsutum). Planta Daninha, 20, 373-379. https://doi.org/10.1590/S0100-83582002000300007

Silva, M. R. M., \& Durigan, J. C. (2006). Períodos de interferência das plantas daninhas na cultura do arroz de terras altas: I-Cultivar IAC 202. Planta Daninha, 24, 685-694. https://doi.org/10.1590/S0100-8358 2006000400009

Singh, K., Kaur, T., Bhullar, M. S., \& Brar, A. S. (2016). The critical period for weed control in spring maize in North-West India. Maydica, 61, 1-7.

Soares, D. J., Gravena, R., \& Pitelli, R. A. (2004). Efeito de diferentes períodos de controle das plantas daninhas na produtividade da cultura da cebola. Planta Daninha, 22, 517-527, 2004. https://doi.org/10.1590/ S0100-83582004000400005

Soares, D. J., Pitelli, R. A., Braz, L. T., Gravena, R., \& Toledo, R. E. B. (2003). Períodos de interferência das plantas daninhas na cultura de cebola (Allium cepa) transplantada. Planta Daninha, 21, 387-396. https://doi.org/10.1590/S0100-83582003000300006

Stagnari, F., \& Pisante, M. (2011). The critical period for weed competition in French bean (Phaseolus vulgaris L.) in Mediterranean areas. Crop Protection, 30, 179-184. https://doi.org/10.1016/j.cropro.2010.11.003

Toledo, R. E. B., Victória Filho, R., Pitelli, R. A., Alves, P. L. C. A., \& Lopes, M. A. F. (2000). Efeito de períodos de controle de plantas daninhas sobre o desenvolvimento inicial de plantas de eucalipto. Planta Daninha, 18, 395-404. https://doi.org/10.1590/S0100-83582000000300002

Tursun, N., Datta, A., Sakinmaz, M. S., Zekeriya Kantarci, Z., Knezevic, S. Z., \& Chauhan, B. S. (2016). The critical period for weed control in three corn (Zea mays L.) types. Crop Protection, 90, 59-65. https://doi.org/10.1016/j.cropro.2016.08.019

\section{Copyrights}

Copyright for this article is retained by the author (s), with first publication rights granted to the journal.

This is an open-access article distributed under the terms and conditions of the Creative Commons Attribution license (http://creativecommons.org/licenses/by/4.0/). 